\title{
Complete sequence of RNA1 and subgenomic RNA3 of Atlantic halibut nodavirus (AHNV)
}

\author{
Ingunn Sommerset ${ }^{1,2, *}$, Audun H. Nerland ${ }^{1}$ \\ ${ }^{1}$ Institute of Marine Research, Department of Aquaculture, PO Box 1870, Nordnes, 5817 Bergen, Norway \\ ${ }^{2}$ Present address: Intervet Norbio AS, Thormøhlens gate 55, Bergen, Norway
}

\begin{abstract}
The Nodaviridae are divided into the alphanodavirus genus, which infects insects, and the betanodavirus genus, which infects fishes. Betanodaviruses are the causative agent of viral encephalopathy and retinopathy (VER) in a number of cultivated marine fish species. The Nodaviridae are small non-enveloped RNA viruses that contain a genome consisting of 2 single-stranded positivesense RNA segments: RNA1 (3.1 kb), which encodes the viral part of the RNA-dependent RNA polymerase (RdRp); and RNA2 (1.4 kb), which encodes the capsid protein. In addition to RNA1 and RNA2, a subgenomic transcript of RNA1, RNA3, is present in infected cells. We have cloned and sequenced RNA1 from the Atlantic halibut Hippoglossus hippoglossus nodavirus (AHNV), and for the first time, the sequence of a betanodaviral subgenomic RNA3 has been determined. AHNV RNA1 was 3100 nucleotides in length and contained a main open reading frame encoding a polypeptide of 981 amino acids. Conservative motifs for RdRp were found in the deduced amino acid sequence. RNA3 was 371 nucleotides in length, and contained an open reading frame encoding a peptide of 75 amino acids corresponding to a hypothetical B2 protein, although sequence alignments with the alphanodavirus B2 proteins showed only marginal similarities. AHNV RNA replication in the fish cell-line SSN-1 (derived from striped snakehead) was analysed by Northern blot analysis, which indicated that RNA3 was synthesised in large amounts (compared to RNA1) at an early point in time post-infection.
\end{abstract}

KEY WORDS: Fish nodavirus $\cdot$ RNA-dependent RNA polymerase $\cdot$ RdRp $\cdot$ RNA1 $\cdot$ Subgenomic RNA 3

Resale or republication not permitted without written consent of the publisher

\section{INTRODUCTION}

Commercial cultivation of Atlantic halibut Hippoglossus hippoglossus started in Norway in the early 1990s, with promising prospects of growth potential and market price. However, until now, successful cultivation of Atlantic halibut has been hampered by recurring outbreaks of viral encephalopathy and retinopathy (VER), also called viral nervous necrosis (VNN), which is caused by a nodavirus (Grotmol et al. 1995, 1997). Affected fish exhibit a range of neurological abnormalities, which can be histologically characterized by vacuolisation and cellular necrosis in the central nervous system and retina (Grotmol et al. 1997, Munday et al. 2002). Nodaviruses are small (25 to $30 \mathrm{~nm}$ ), unenveloped icosahedral viruses with a genome that consists of 2 molecules of positive-sense (+) single-stranded (ss) RNAs. RNA1 $(3.1 \mathrm{~kb})$ encodes protein A, the viral part of the RNA-dependent RNA polymerase (RdRp), while RNA2 (1.4 kb) encodes the capsid protein of the virus, protein $\alpha$ (reviewed by Schneemann et al. 1998). The Nodaviridae are divided into 2 genera, the alphanodaviruses, which infect insects and the betanodaviruses, which infect fishes. The alphanodaviruses include the Pariacoto virus $(\mathrm{PaV})$, the Nodamuravirus $(\mathrm{NoV})$, the Boolarra virus (BoV), the flock house virus (FHV) and the black beetle virus (BBV) (Scherer et al. 1967, Longworth \& Archibald 1975, Scotti et al. 1983, Reinganum et al. 1985, Zeddam et al. 1999). In addition to RNA1 and RNA2, a subgenomic transcript of RNA1, RNA3, is present in insect nodavirus-infected cells (Friesen \& Rueckert 1982, Guarino et al. 1984, Harper 1994, Johnson et al. 2003). RNA3 is 3' co-terminal with RNA1; it is capped but not polyadenylated, and is not present in the virus particle (Guarino et al. 1984). NoV RNA3, FHV and BBV encode 2 small non-structural proteins, B1 and B2, in overlapping reading frames (Dasmahaptra et al. 1985, Harper 1994, Johnson et al. 
2003). B1 is translated in the same reading frame as protein A, while B2 is translated in a +1 reading frame. PaV RNA3 has the coding potential of B2 and a second, smaller open reading frame (ORF) corresponding to the C-terminal region of protein A (Johnson et al. 2000), whereas the B1 ORF is absent from BoV RNA3 (Gene Bank Accession No. AF329080; Harper 1994). The function of protein B1 is not known, while the function of the FHV B2 protein has recently been identified as a potent RNA-silencing inhibitor that renders infected plant cells or Drosophila spp. cells less resistant to the virus (Li et al. 2002).

Independent of its protein encoding potential, it has been suggested that RNA3 may act as a transactivator in the replication of RNA2 (Eckerle \& Ball 2002). In contrast, RNA3 synthesis is suppressed by the replication of RNA2 (Zhong \& Rueckert 1993). RNA3 has not been characterized in fish nodaviruses, although Delsert et al. (1997) detected an RNA segment of $0.4 \mathrm{~kb}$ in sea bass Dicentrarchus labrax larvae infected with $D$. labrax encephalitis virus (DlEV). Iwamoto et al. (2001) also detected a faster migrating RNA (0.4 kb) from fish cells (E-11 cell line, a cloned version of SSN1) that had been transfected with in vitro transcribed striped-jack nervous necrosis virus (SJNNV) RNA1 and RNA2. The complete nucleotide sequence of the RNA1 segment is known for the fish nodaviruses SJNNV (Nagai \& Nishizawa 1999) and greasy grouper nervous necrosis virus (GGNNV) (Tan et al. 2001). A partial RNA1 sequence also exists for the Japanese flounder nervous necrosis virus (GenBank AB046376). Partial RNA2 nucleotide sequences exist for several other fish nodaviruses. In phylogenetic analyses based on alignments of the variable (T4) region of the viral capsid gene, fish nodaviruses have been classified into 4 genotypes: SJNNV, tiger puffer nervous necrosis virus (TPNNV), Barfin flounder nervous necrosis virus (BFNNV) and redspotted grouper nervous necrosis virus (RGNNV) (Nishizawa et al. 1997). The nodavirus that affects Atlantic halibut belongs to the BFNNV genotype together with nodaviruses from Japanese barfin flounder Verasper moseri Pacific cod Gadus macrocephalus and Atlantic cod Gadus morhua, all cold-water fish species (Aspehaug et al. 1999, Grotmol et al. 2000, Johnson et al. 2002). In this study we report the full-length sequence of AHNV RNA1, the nucleotide sequence of the subgenomic RNA3, and its presence early in the infection cycle of AHNV-infected fish cells.

\section{MATERIALS AND METHODS}

Generation and screening of cDNA library from AHNV-infected Atlantic halibut larvae. AHNV-in- fected halibut larvae were collected from a commercial rearing facility in Western Norway during a natural outbreak in June 1999. The presence of AHNV in diseased larvae was confirmed by means of immunohistochemistry and reverse transcription (RT)-PCR, as described by Grotmol et al. (1999, 2000). The nodavirus strain was denoted AH99NorA, and the material was stored at $-80^{\circ} \mathrm{C}$ until used. Total RNA was extracted from 30 diseased larvae using Trizol® Reagent (Life Technologies) according to the manufacturer's protocol. cDNA was synthesised using the Universal RiboClone ${ }^{\circledR}$ cDNA synthesis system (Promega Corporation), and blunt-ended cDNA was cloned into the lambda Zap II vector (Stratagene Inc.), using EcoR I adaptors. Recombinant lambda were packed in vitro with Gigapack Gold Packing Extract and plated on E. coli XLI-blue cells (Stratagene Inc.). Plaques were transferred to nylon membranes (Roche, Germany), fixed under UV-light at an intensity of $120 \mathrm{~mJ} \mathrm{~cm}^{-2}$ (StrataLinker, Stratagene Inc.), and the cDNA library $\left(1 \times 10^{5}\right.$ plaque-forming units, pfu) screened using 2 digoxigenin (DIG)-labelled DNA probes based on the sequence of SJNNV RNA 1 (Nagai \& Nishizawa 1999). The probes were made using cDNA from SJNNVinfected SSN-1 cells (Strain SJ93Nag; Nishizawa et al. 1997) as templates in a PCR-based DIG-dUTP incorporation protocol (Roche). Probe 1 (427 bp) was made using the primer-pairs SJRNA1-F1 (5'-CGGTGTGGTTGAGAAATGTG-3') and SJRNA1-B1 (5'GGTGATGCCAGTAATGTCGC-3'), and probe 2 (161 bp) was made using the primer-pairs SJRNA1-F2 (5'AGTGGCTAGGGATTTCGTGC-3') and SJRNA1-B2 (5'-GGAACGCCTTGACGATCATA -3'). Hybridisation with $10 \mathrm{ng} \mathrm{ml}^{-1}$ of each probe was performed overnight in Standard hybridisation buffer (Roche) at $67^{\circ} \mathrm{C}$, followed by a post-hybridisation wash with $0.5 \times \mathrm{SSC}$ (0.075 mM NaCl, 7.5 mM sodium citrate, $\mathrm{pH} 7.0$ ), $0.1 \%$ sodium dodecyl sulfate (SDS) at $68^{\circ} \mathrm{C}$. Positive plaques were detected using the DIG Luminescence Detection Kit, with anti-digoxigenin-AP and the chemiluminescence substrate CSPD® (Roche). Single positive plaques were cored and subjected to in vivo excision with the ExAssist Helper phage (Stratagene Inc.), according to the manufacturer's instructions. Insert DNA, freed from the lambda vector in the form of a pBluescript phagemid, was sequenced using the ABI PRISM ® BigDye Primer Cycle Sequencing Kit (Applied Biosystems) with the vector primers reverse M13 and $\mathrm{T} 7$ primer.

Cloning RNA1 and RNA3 ends. The $5^{\prime}$ end of RNA1 and RNA3 was determined by 5'RACE (rapid amplification of cDNA ends) using the GeneRacer Kit (Invitrogen) according to the manufacturer's instructions. The 5' end of RNA1 was obtained by RTPCR using the GeneRacer 5' primer (5'-CGACTG- 
GAGCACGAGGACACTGA-3') together with the gene-specific primer 5'-GCCACTCTTCTCGACAACGC-TCA-3'. This RT-PCR product (approx. 400 bp) was cloned into the plasmid vector pCR4-TOPO (Invitrogen) and sequenced using the ABI dye primer cyclesequencing kit (Applied Biosystems). The $5^{\prime}$ end of RNA 3 was obtained and sequenced in a similar way, using the GeneRace 5' primer in combination with a gene-specific primer (5'-GAACGTGAAGGCGGCATGCT-3') binding around $400 \mathrm{bp}$ downstream of the anticipated transcription start for RNA 3. The $3^{\prime}$ end sequence of RNA1 was determined by ligating (T4 RNA ligase) dephosphorylated and decapped RNA. Using RT-PCR with primers specific for the $5^{\prime}$ end (5'-ATGGTTTCAGTAGCACTATTCCGCTC-3') and the 3' end of RNA1 (5'-ATGGAGACAGAGTAGAAGGAGCTGCC-3'), a product was generated covering the junction of the head-to-tail RNA molecule. The PCR product was cloned into pCR4-TOPO and sequenced.

Identification of RNA3 in AHNV-infected cells by Northern blot analysis. SSN-1 cells derived from the striped snakehead fish Ophicephalus striatus (Frerichs et al. 1996) were grown in $75 \mathrm{~cm}^{2}$ cell-culture flasks (Falcon Primaria, Becton Dickinson Labware) at $25^{\circ} \mathrm{C}$ until 70 to $80 \%$ confluence and inoculated with $1.0 \times 10^{8} \mathrm{TCID}_{50}$ of AHNV (third passage of Strain AH95NorA) at $20^{\circ} \mathrm{C}$, as described by Dannevig et al. (2000). Cells were washed and harvested $8,24,48$ and $120 \mathrm{~h}$ post-infection using a cell scraper and low-speed centrifugation $(1000 \times g)$. Total RNA was extracted from virus-infected SSN-1 cells using an RNeasy Mini Prep Kit (Qiagen). From each sample, $5 \mu$ g RNA was resolved by agarose/formaldehyde gel electrophoresis, according to Sambrook \& Russell (2001). RNAs were transferred to nylon membranes (Roche) according to the manufacturer's instructions and fixed by UV light at $120 \mathrm{~mJ} \mathrm{~cm}^{-2}$. Hybridisation was performed with four 3'DIG-labelled ss DNA oligoprobes specific for the AHNV RNA1/RNA3 and AHNV RNA2 positive and negative strands, using $10 \mathrm{pmol} \mathrm{ml}^{-1}$ probe in standard hybridisation buffer (Roche) at $60^{\circ} \mathrm{C}$. Probe RNA1/3 ss (+) 5'-TGCTGATCGATCGCCTGTTGGATTTGTTCC-3', Probe RNA 1/3 ss (-) 5'-GGAACAAATCCAACAGGCGATCGATCAGCA-3', Probe RNA2 Ss (+) 5'-TGTTCTGCTTTCCCACCATTTGGCAACGACCGCACCG-3', and Probe RNA2 ss (-) 5'GGTTGGTACTCCTGTGTGCCGGCAACAACACTGACGT-3' were synthesised and 3' end DIG-labelled by OligoGold (MedProbe). Post-hybridisation washes were done twice with $0.5 \times \mathrm{SSC}, 0.1 \times \mathrm{SDS}$ at $30^{\circ} \mathrm{C}$, and detection was performed with anti-DIG AP and CSPD $®$ substrate (Roche) and X-omit film (Kodak).

Sequence analysis. The nucleotide sequences were assembled and analysed using the Vector NTI ${ }^{\mathrm{TM}}$ application programmes (InforMax®). Amino acid (aa) se- quences and nucleic acid sequences were aligned using AlignX in the Vector NTI ${ }^{\mathrm{TM}}$ package based on the Clustal W algorithm (Thompson et al. 1994). Multiple and pairwise alignment of protein sequences was performed using a Gonnet score matrix with a gap-opening penalty of 5 and a gap-extension penalty of 0.01 . DNA sequences were aligned using swgapdnamt matrix with a gap-opening penalty of 10 and gapextension penalty of 6.66 (default settings). RNA secondary structure was predicted using Mfold Version 3.1 (Zuker et al. 1999) at the mfold server at Rensselaer Polytechnic Institute, New York, and by means of RNA structure Version 3.7 (Mathews et al. 1999). Transmembrane domain analysis was preformed using TMpred (available at: http://www.ch.embnet. org/software/TMPRED_form.html), DAS (available at: http://www.sbc.su.se/ miklos/DAS/maindas.html), hydrophobicity plot (available at: http://bioinformatics. weizmann.ac.il/hydroph/plot_hydroph.html) and secondary structure predictions using ExPACy, proteomics tools (available at: http://us.expasy.org/tools/).

The nucleotide sequence of RNA1 and RNA3 was deposited in the EMBL nucleotide sequence database under Accession No. AJ401165 (updated 21 January 2003).

\section{RESULTS AND DISCUSSION}

\section{AHNV RNA1 and ORF-A}

The nucleotide sequence of AHNV RNA1 was obtained by DNA sequencing of 8 overlapping clones from the cDNA library, and the $5^{\prime}$ and $3^{\prime}$ terminal ends were determined by 5'RACE and RNA ligation. The complete RNA1 nucleotide sequence was 3100 bases and contained 1 major ORF (called ORF protein A) at nucleotides (nt) 79 to 3021, encoding a 981 aa polypeptide with a deduced molecular mass of $110 \mathrm{kDa}$. A BlastX search (Altschul et al. 1997) using the AHNV RNA1 sequence revealed significant matches $(\mathrm{E}<$ $10^{-5}$ ) with the protein A sequence of GGNNV, SJNNV, the partial sequence of JFNNV RNA1, and the protein A sequences of the 5 known insect nodaviruses. Pairwise sequence-alignment of the AHNV protein A sequence with the other fish nodaviruses demonstrated high sequence identity (Table 1); the amino acid sequence identity between AHNV and GGNNV, and AHNV and SJNNV was 90 and $89 \%$, respectively. The sequence identity between protein A of GGNNV and SJNNV, in viruses that infect geographically and biologically closer related species of fish, was also $89 \%$. The differences in the protein A encoding-region between the fish nodaviruses were all due to nucleotide substitutions, except two 3-nucleotide deletions in the AHNV RNA1 sequence which made the 
Table 1. Percentage of amino acid sequence identities between deduced protein A sequences of fish and insect nodaviruses. For comparison, sequence identities between capsid proteins are shown in parentheses (bottom left part of table). Pairwise alignment was performed using Vector NTI's AlignX (Gonnet score matrix, gap-opening penalty = 5, gap-extension penalty = 0.01). AHNV: Atlantic halibut virus; GGNNV: greasy grouper nervous necrosis virus; SJNNV: striped jack nervous necrosis virus; PaV: Pariacoto virus; BoV: Boolarra virus; FHV: flock house virus; BBV: black beetle virus. The accession number for RNA1 (encoding protein A) is given for each nodavirus

\begin{tabular}{|lccccccccc|}
\hline Virus & Access. no. & AHNV & GGNNV & SJNNV & PaV & NoV & BoV & FHV & BBV \\
\hline AHNV & AJ401165 & & 90 & 89 & 26 & 21 & 26 & 25 & 24 \\
GGNNV & AF319555 & $(89)$ & & 89 & 25 & 20 & 26 & 25 & 24 \\
SJNNV & NC_003448 & $(85)$ & $(86)$ & & 26 & 21 & 25 & 25 & 24 \\
PaV & AF171942 & $(18)$ & $(17)$ & $(16)$ & & 24 & 23 & 22 & 21 \\
NoV & AF174533 & $(22)$ & $(22)$ & $(22)$ & $(37)$ & & 40 & 41 & 39 \\
BoV & AF329080 & $(20)$ & $(20)$ & $(20)$ & $(38)$ & $(44)$ & & 86 & 78 \\
FHV & X77156 & $(20)$ & $(18)$ & $(18)$ & $(38)$ & $(49)$ & $(50)$ & & \\
BBV & X02396 & $(22)$ & $(20)$ & $(20)$ & $(37)$ & $(49)$ & $(51)$ & $(88)$ & \\
\hline
\end{tabular}

deduced protein A 1 aa shorter than GGNNV and 2 aa shorter than the SJNNV protein A sequence.

A similar comparison of protein A sequences within the insect nodaviruses revealed a much lower level of similarity within that genus (Table 1, and Johnson et al. 2001). In fact, the identities between the geographically and biologically separated insect nodavirus $\mathrm{PaV}$ and the other insect nodaviruses (approximately $23 \%$ ) are as low as the variation between the fish and insect nodaviruses (approximately $24 \%$ ). Interestingly, the $\mathrm{PaV}$ protein $\mathrm{A}$ sequence showed a higher identity to the fish nodavirus RdRps than to the insect nodavirus sequences, while the $\mathrm{PaV}$ capsid protein sequence showed a very low identity to the fish nodavirus capsid proteins (Table 1). Although very speculative, it is tempting to consider if the RNA1 and RNA2 molecules in $\mathrm{PaV}$ might have evolved from 2 different sources. Although highly variable in amino acid sequence, multiple sequence alignment showed a clear relationship in organization of the RdRp domain within the fish and insect nodaviruses (Fig. 1). In all RdRps, 3 motifs are completely conserved including a GDD-consensus sequence which is believed to define a highly conserved 'polymerase site' (Poch et al. 1989, Delarue et al. 1990). The RdRp signature sequence has been defined as $\mathrm{D} X_{3}(\mathrm{FYWLCA}) X_{0-1} \mathrm{D} X_{\mathrm{n}}(\mathrm{STM}) \mathrm{G} X_{3} \mathrm{~T} X_{3}$ (NE) $X_{\mathrm{n}}(\mathrm{GS}) \mathrm{DD}$ (Koonin \& Dolja 1993), where $X$ denotes any residue, residues in parentheses are amino acids allowed in this position, and subscripts denote the number of residues present. As discussed by Johnson et al. (2001), this signature was precisely matched by alignment of each of the 5 insect nodaviruses and the SJNNV protein A sequence. Addition of the AHNV (and GGNNV) protein A sequences to this alignment also resulted in a precise match of the RdRp signature in the C-terminal part of the molecules (core residues in the RdRp signature are boxed in Fig. 1). This strongly suggests that the major ORF present in the RNA1 sequence of AHNV encodes the viral part of the RdRp.

Since nodavirus RNA is capped and replicated in the cytoplasm (Dasgupta et al. 1984, Dasmahapatra et al. 1985), protein A is expected to have an RNA guanylyland methyltransferase activity. A putative guanylylation motif (HNA)XH in the N-terminal part of the protein has been proposed by Johnson et al. (2001) as a good candidate for capping activity. The HXH motif was evident at positions 74 to 76 of the AHNV, as well as in the SJNNV and GGNNV sequence, and at position 96 to 98 in the PaV sequence (Fig. 1), while the other insect nodaviruses had an NXH motif. As noted by Johnson et al. (2001) and seen in the multiple alignment in Fig. 1, a relatively high level of conservation was observed at the $\mathrm{N}$-terminal region of the fish and insect nodavirus RdRps downstream of the capping motif. The D(VI)DYY sequence starting at aa position 144 (numbered relative to the AHNV sequence) was outstanding, but an attempt to search for any protein motif having this sequence was unsuccessful. The cellular localisation of the RdRp of FHV has recently been identified as an outer mitochondrial membrane complex, in which the N-terminal of the protein (aa 15

Fig. 1. Multiple alignment of the amino acid sequence encoded in open reading frame (ORF) of fish and insect nodavirus RNA1 segments. Sequence alignment by AlignX (Clustal W-based) using Gonnet matrix with gap-opening penalty of 5 and gap-extension penalty of 0.01 . Completely conserved amino acids in aligned sequences are shaded, core residues of RdRp signature are boxed, and putative capping motif is marked with line above relevant sequences. Computer-predicted transmembrane domain (TMD) in N-terminal AHNV protein A sequence, and predicted TMD of FHV protein A (Miller \& Ahlquist 2002) are italicised and underlined. Virus abbreviations as in legend to Table 1 
AHNV

GGNNV

SJNNV MEEHIPLPSQYESPKALPPRVPSSR-WLRSLRPRLANSCLALKIRAHESLVKIR-LCKPYDAQ-----SRSKI IEKVIERRETRKTLAHQLKDLKLVPVARD--HTHGRAAKFRTSANIWMNEAMRA -MTLKVILGEHQITRTELLVGI--------ATVSGCGAVVY-CISKFWGYGA---IAPYPQSGGNRVTRALQRAVIDKTKTPIETRFYPLDSLRTVTPKRVADNGHAVSGAVRDAARRLIDESITA :-MTLKVILGEHQITRTELPVGI-------ATVSGCGAVVY-CISKFWGYGA---IAPYPQSGGNRVTRALQRAVIDKTKTPIETRFYPLDSLRTVTPKRAVDNGHAVSGAVRDAARRLIDESITA MLNYETI INGASSALNIVSRALGYRVPLAKSLALVAGSCVVYKI IVHRRTLVAFLVIGPYATVVQHRLPMALQRAI IEYTREDREISLFPQNS IVSAEHARKADNGHPISGGTRDVARETISLAIRA

: N-LKRILRDITGITALCGFLYNKLGMAPFGDPVTMFTVDQFKMGEHRNIVSIVP-FATCRSNLLKISEYGAELEYMRYQQRNNIANFNAVTYISE-EGPLISLGLEGNFASVQLPLQDFENVRTAYE : N-LMQILRDITGVTAICSFLYTKLGIAPFGDPVTMFTVDQFKMGEHRNIVSIVP-FATCRSNLLKISEYGAELEYMRYQQRNNIANFNAVTYISE-NGPLISLGLEGNFASVQLPLQDFENIRTAYE S-LKQILRDITGITALCGYLYLKLGIAPFGDQVTLFTVDQFKMGEHRNIVSIVP-FATCRSNLLKISEYGAELDYMRYQQRNNNANFNAVTYISQ-EGPLISLGLEGNFASVQLPLQDFENIRTAYE EWFLQLPLRMIGLEKVG---YHKI----H------HCRPWTDCPDRALVYTI I QYVIWRFNWIDTELHVRKLKRIEYQD-ETKPGWNRLEYVTDKNELLVS IGREGEHAQITIEKEKLDMLSGLSA : EWFLQLPLRMIGLEKVG---YHKI----H------HCRPWTDCPDRALVYTIPQYVIWRFNWIDTELHVRKLKRIEYQD-ETKPGWNRLEYVTDRNELLVSIGREGEHAQITIEKEKLDMLSGLSA : EWFLQLPLRMIGLEKVG---YHKI----H-----YCRPWTDCPDRALVYTIPQYVIWRFNWIDTELHVRKLKRIEYQD-ETKPGWNRLEYVTDRNELLVSIGREGEHAQITIEKEKLDMLSGLSA : A---WFARAVGLTKSQ---IHKV----H-----YCRPWPQSPHRALVWCLPVASYWRFTFIPTDLHTRTLRRVRYQD-TSRPGWNSIVSTGS -EGLNISLGREGADHCVTIPKVHYDMLMGLSS

: LSKTNNLSDTVRRSGRPCKEAAI IHKCLQAECVLASEVVHKPGDLARHYQAVGSLYDVDPAEQGKCYAREYAPGPLTQTAVFPNESRSNER-ATIDGRIAGPQAKAKSREHITPRMRKVARDFVRHL : 470 : LSKTNNLSDTVRRSGRPCKEAAI IHKCLQAECAVVSEVVHKPGDLARHYQAVGSAYDTDPAEQGKCYAREYAPGPLTQTAVFPSESRSNEL-ATIDGRIAGPQAKAKSREHITPKMRKVARDFVHHL : 470 : LSKNNNLSDTVRRARSCKEAAI IHKCLQAGCDLASEVVHKPGELARHYQALGDTYDIDPSEQGKCYAREYAPGPLTQTAVFPSESRSNEL-ATIDGRIAGPQAKAKSREHITPKMHKVARDFVRHL : 470 : TQSVNARLIGMGHKDPQYTSMIVQYYTGKKVVSPISPTVYKP-TMPRVHWPVTSDADVPEVS-----ARQYTLPIVSDCMMMPMIKRWETMSESIERRVTFVANDKKP----SDRIAKIAETFVKLM : $\quad 467$ - TOSVNVRLIGMGHKDPOYTSMIVOYYTGKKVVSPISPTVYKP-TMPRVHWPVTSDADVPEVS-----AROYTLPIVSDCMMMPMIKRWETMSESIERRVTFVANDKKP----SDRIAKIAETFVKLM : 467 AQSIVRLIGMGHKDPQYTSMIVQYYTGKKVVSPISPIVYKP-TMPRVHWPVISDADVPEVS-----ARQYTLPIVSDCMMPMIKRWEIMSESIERRVTFVANDKKP----SDRIAKIAETEVKLM : 467 : AQSLSSRMIGLKYTDPSVLATVAQYYQGKNVEVADADRIGRA-INPKVHWPAHVEVDEAEVS-----ARVYASPLVSDENMMPMIKRWETLSLSLDRRVTFQRNPKVP----GKRLRAYAIEFVDLV : 475
$:$ TOSVNARLIGMGHKDPLYTSMIVQYYTGKKVVLSVAPTVYRP-TMPRVHWPVTSDADVPEVS-----ARQYTKPIISDCMMMPMIKRWETMSESIERRVTFVANNKKP----SDAVAKIAAEFVSLM : VPIAGTGRPYPLTYVEEQQTKPLQ--RARNDANRYHDEFTMMVKAFQKKEAYNAPNYPRNISTVPHTQN-VKLSSYTYAFKASVLQHVP---WYMPTHTPAEIADAVQNLAASST-ELVETDYSKFD
VPTAGLGRPYPLTYVEEHOTKPLO--RARNDANRYHDEFTMIVKAFOKKEAYNAPNYPRNISTVPHTON-VKLSSYTYAFKEAVLOHVP---WYMPTHTPAEIAEAVOSLAASST-ELVETDYSKFD VPEPGVGHPWDTAAVREVQDNRQQKARINMVAATVSTHSSNRLKAFIKAEAYAATNDPRNITTMAPELT-LMMSCFTYAFKEKILYEQP---WYGPGKTPKQVGRRLQSIAKHGT---LESDYSRFD : 569 : NGPFKDLDPLSIEETIERLNKPSQQLQLRAVFEMIGVKPRQLIESFNKNEP--GMKSSRI ISGFPDILFILKVSRYTLAYSDIVLHAEHNEHWYYPGRNPTEIADGVCEFVSDCDAEVIETDFSNID : 592

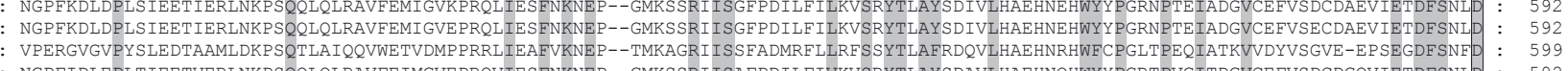
: NGPFIDLEPLTIEETVERLNKPSQQLQLRAVFEIMGVEPRQVIESENKNEP--GMKSSRIISAFPDILFIVKVSRYTLAYSDAVLHAEHNQHWYYPGRTPVGITDGVCEFVSDCDGQVIETDFSNLD : 592

GTFLRFMRECVEFAIYKRWVHLDHLAELSQLLANELQAPAVTR-LGLKYDPDCSRISGSALTIDGNSIANAFVSYLANR-LAGMDDD--EAWSWIGIVYGDDGLRSG-NVSDTLLTDTASSLGEDLK : 712 GTFLRFMRECVEFAIYKRWVHLDHLPELTTLLANEIQAPAVTR-LGIKYDPDCSRISGSALIIDGNSIANAFVSYLAGR-MAGMDDD--EAWSWIGIVYGDDGLRSG-NVSNELLTNTASSLGFDLK : 712 GTFLRFMRENVEFAIYKRWVHLDHLTELSTLLGNELQAPAVTR-LGIKYDPDCSRISGSAITIDGNSIANAFVSYLAGR-QAGMDDD--EAWTWIGIVYGDDGLRSG-NVSDALLSKTASSLGEDLK : 712
GSISEWLQKNVVKAAYMRFFKEHQRTEFQSWFSKVFMQMGTTT-AGVRYEAGWGTRSGSPIITDGNTMLNAFVVYCCYRKLCHTPAEAWRKLSQGALLTGDDAVLAHENGLEPALLDVVKNLLLKVE :

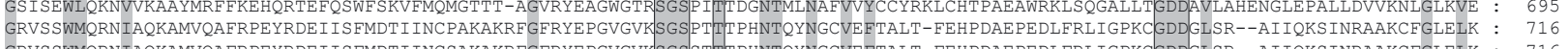
GRVSSWMQRNIAQKAMVQAFRPEYRDEI ISFMDTI INCSAKAKRFGFRYEPGVGVKSGSSTIIPHNTQYNGCVEFTALT-FEHPDAEPEDLFRLIGPKCGDDGLSR--AIIQKS INRAAKCFGLELK : 716
GTVSEWLORHVMNAVYLRYFNHRAQRDLRSYTDMLVSCPARAKRFGFAYDAGVGVKSGSPTICDLNTVCNGFLOYCSIR-MTHPELTPIDAFRLIGLAFGDDSLFE--RRFAKNYAKVSAEVGMVIK GTVSEWLQRHVMNAVYLRYFNHRAQRDLRSYTDMLVSCPARAKRFGFAYDAGVGVKSGSPTICDLNTVCNGFLQYCSIR-MTHPELTPIDAFRLIGLAFGDDSLFE--RRFAKNYAKVSAEVGMVLK : 723
GRVSGWMQRNIAQKAMVQAFRAEYRDEIISFMDTIINCPAKAKRFGFRYEPGMGVKSGSPTITPHNTQYNACVEYTALK-FEYPDANPEDLFSLLGPKCGDDGLAR--ATIQKTINRAAKCYGLELK : 716

: IVNRAPRGSPVTFLARVYLDPWSSPASVQSPFRTLLKLHTTC-DTQSEIEDIGWAKTQAYLVTDCKTPFIGHWC----RAYQRNCTARVVQY-----ADYNDIPFWVKNDDHLGNSWPQS--DSVDWN : 828 IVNRAPRGSPVTLSRVYLDPWSSPASVQSPLRTLLKLHTTC-DTQSEIDDIGWAKTQAYLVTDSKTPFIGHWC----RAYQRNCTARVVQY----ADYADIPFWVKNDDHVGNSWPQS--ESDDWN : 828

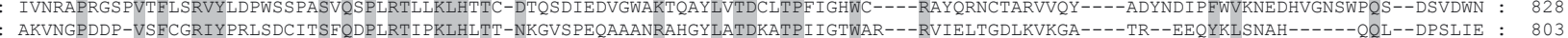

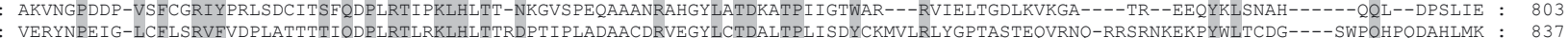
: VERYNPEIG-LCELSRVFVDPLATTTTIQDPLRTLRKLHLTTRDPTIPLADAACDRVEGYLCTDALTPLISDYCKMVLRLYGPTASTEQVRNQ-RRSRNKEKPYWLTCDG----SWPQHPQDAHLMK : 837 VERYNPEIG-LCELSRVFVDPLATTTTI IDPLRTLRKLHLTTRDPTIPLADAACDRVEGHLCTDALTPLISDYCKMVLRLYGPTASTEQVRNQ-RRSRNKEKPYWLTCDG----SWPQHPQDAHLMK : 837 $\begin{array}{lll}: & \text { IERFDPAQG-ITELARVYPDPYTSTTSFQDPLRTWRKLHLTTRDPTIPLATAAIDRVEGYLVTDGLSPLTGAYCRMVKRVYEAGGAEDAAKRRSRKSHSREKPYWLTVGG----AWPQDVKDVDLMF : } \\ : \text { VEKYNPEVG-LCELSRVFVDPLNTPTTIQDPLRTLRKLHITTRDPTIPIADAACDRVEGYLCTDAHTPLISEYCRMVQRLYGPKTSTRDVREA-RRSRNKEKPYWLTCDG----SWPQHPQDALIMK } & : \text { 837 }\end{array}$

: DVVANELGLTTAELLKHIALLEAYTGPTSGLPRLTTSIDLEPKMSVALDGEVQA-GPSQQ-QT-DKDGTNPTGDRSAPRRARTALPGVDGHTRC--TRRS--DRGPGERDANVRDKRPR-----RSM : 943 DIVANELGVTTAELIKHLALIDAYAGPISGLPRLTTSIDLEPKMSVALDGEIQA-GPSQN-KT-SKDGTNPTSDRSAPRRARAALPGDDGHARR--SRRS--DRDPGKRDAHVRDKRPR-----RSS : 943 DVVANELGLTTAELLKHLAALDAYTGPVSGLPRLTTSLDLEPKMPVALDGEVQA-GPSQQPQT-DKDGTSPTGDRSAPRRARTALQDADGRACR--SRRS--DRSPGKRDANVRDKRQR-----RST : 944 : TAMANILGIDVGELKALDKAVSEAK-ALDQMPVVLGN-CYKHKIEAVVGGEVVGPGPRVETVEPNHE-QSSGTPEVVPEMAGHSERRDKSSNPRPGGKAEGLSSKAGKPRVPTRPAADR-----KAA : 922 QVLIKRTAIDEDQVDALIGRFAAMKDVWEKITHDSE--ESAAACTFDEDGVAPN-SVDESLPM-LNDAKQTRANPGTSRPHSNGGGSSHGNELP--RRTE--QRAQGPRQPARLPKQGK-----TNG : 951

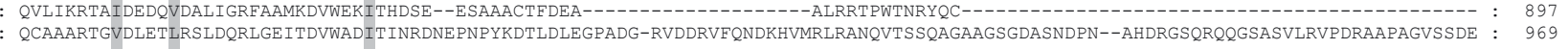
: QIVVSRTGIDEDTVDKLIGRFAAMKDVWEPITLESE--ESKAAQTIDEEGVAPG-SVDESLLK-LNDAKQTRSNSGTSGPHTKGGGSGTGNELP--RSTK--QRAKGPRQSAGLPKQGK-----ANS : 951

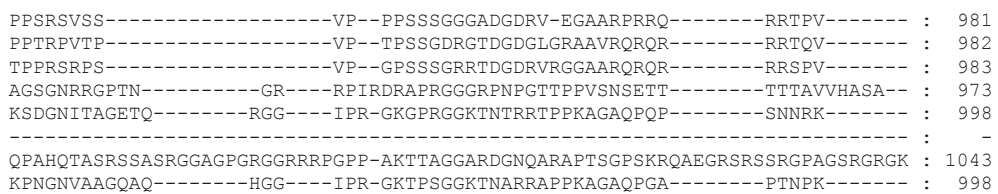


Virus 5'UTR:

$5^{\prime}$

GGNNV : UAACAUCACCUUCUUGCUCUGUUGAGUA-AUCACUUACGCAAGGUUACCGUACA-GCUUAGACAACGACAAGUCUACGCCAUG... AHNV : UAACAUUAUCU-CUUGCUCUGUUGAGAU-AUCACUUACGCAAGGUUACCGUUUAAGCAUACACAACGACAAGUGUAAGCCAUG... SJNNV : UAACAUCAGCU-CUUGCUCUGUUGUUUUGAACACUUACGCAAGGUUACCGUUUA-GCAUACAAUACGACAAUUGUAAGCCAUG...

Virus 3'UTR:

AHNV : ...UAGGCAG-UCACCUGCCCGCUCCCACCCCCCCCGGGCCUAUGGGCCCCCUAGUCAGCUUUACGCUGUCAUACGCUUAGGCGGNNV : ...UAGACAGGUCACUUGCCUGCUCCCACCCCUUG-GACCGUUUUGGUCCCUUAAUCAGCUUUAUGCUGUCCUACGCUUCGGCSJNNV : ...UAGGCGAGUCACCUGCCCGCUCCUACCCCCCCCGGACC-AUUGGUCCCCUAGUCAGCUUUAUGCUGUCCUACGCUUCGGCG

$$
\text { Stop }
$$

Fig. 2. Alignment of nucleotide sequences of untranslated regions (UTRs) of fish nodavirus RNA1 segments. Initiation and termination codons of the protein A ORF are underlined. Virus abbreviations as in legend to Table 1

to 36) contains a transmembrane domain (Miller \& Ahlquist 2002). Analysis of the protein A sequence of AHNV using different computer programs predicted with a high probability a transmembrane segment in almost the same N-terminal region as FHV (aa 6 to 25, Fig. 1). However, there were also indications of a region corresponding to a transmembrane helix at aa positions 150 to 169 and 225 to 247, and PSORT predicted the AHNV protein as being a nuclear protein (with $74 \%$ probability). Further studies are needed to determine the cellular localisation of fish nodavirus RdRps.

Authentic termini are reported to be of importance for efficient RNA replication (Ball 1992, 1995, Ball \& Li 1993), and it is interesting that both the length and, to a high extent the sequence, are conserved in the $\mathrm{X}$ untranslated regions (UTRs) of the fish nodaviruses (Fig. 2). The AHNV RNA1 sequence had a 5' UTR of $79 \mathrm{nt}$ and 3' UTR of $76 \mathrm{nt}$, identical in length to that of GGNNV (Tan et al. 2001) and 1 nt shorter at the 3' UTR than SJNNV RNA1 (Iwamoto et al. 2001). Compared to the insect nodaviruses 5' UTRs, which vary from 21 to 39 nt (Johnson et al. 2001), the 5' UTRs of fish nodaviruses are relatively long. The 3' UTR of the fish nodaviruses' RNA1 are all very C-rich (41\%) and the average \% GC is 63. This is in agreement with the insect nodavirus 3' UTR (Johnson et al. 2001), although the conserved $\mathrm{C}$-rich motif [CCCC(X)nCGC] found in the 3' UTR of RNA1 and RNA2 of BBV, FHV and BoV (Kaesberg et al. 1990) was not found in AHNV or any of the other fish nodaviruses. As with the 5' UTR of fish nodavirus RNA2 (Iwamoto et al. 2001, Tan et al. 2001, unpubl. results for AHNV), the 5' terminal nucleotides, disregarding the cap, are UAA. As discussed by Dasmahapatra et al. (1985) and Kaesberg et al. (1990), secondary structures at the 3' UTR might be responsible for recognition/binding of the RNA replicase. A common pattern of secondary structure of the fish nodavirus RNA1 3' UTRs was not obtained using RNA secondary-structure prediction programs based on the Zucker algorithm.

\section{RNA3 and protein B2}

The subgenomic RNA3 of AHNV was determined by $5^{\prime}$ RACE and a downstream lying primer corresponding to the $3^{\prime}$ end of RNA1. A single band corresponding to approximately $400 \mathrm{nt}$ was revealed by RT-PCR, and DNA sequencing of several clones of the RT-PCR product revealed a 5' RACE-generated product of 371 nt which corresponded to nt 2730 to 3100 of the AHNV RNA1 sequence. A transcript corresponding to this molecule was also demonstrated by Northern blotting of RNA from AHNV-infected SSN-1 cells (Fig. 3). Positive-sense RNA3 was detected $24 \mathrm{~h}$ post-infection together with both positive-sense RNA1 and RNA2 (not shown), although the RNA1 band was very weak at this point in time. In addition, an RNA molecule of approximately $1.7 \mathrm{~kb}$ was hybridising with the RNA1/3 ss (+) probe (Fig. 3, Lane 5). This could consist of dimers of RNA2 and RNA3, which have been reported to be present during the replication of insect nodaviruses (Albarino et al. 2001), or a degradation product of RNA1. No cytopathogenic effect (CPE) was evident in SSN-1 cells until $120 \mathrm{~h}$ post-infection, probably due to a sub-optimal temperature $\left(20^{\circ} \mathrm{C}\right)$ for both cells and virus (Totland et al. 1999, Dannevig et al. 2000). Therefore, the presence of AHNV RNA3 $24 \mathrm{~h}$ post-infection is in correspon- 


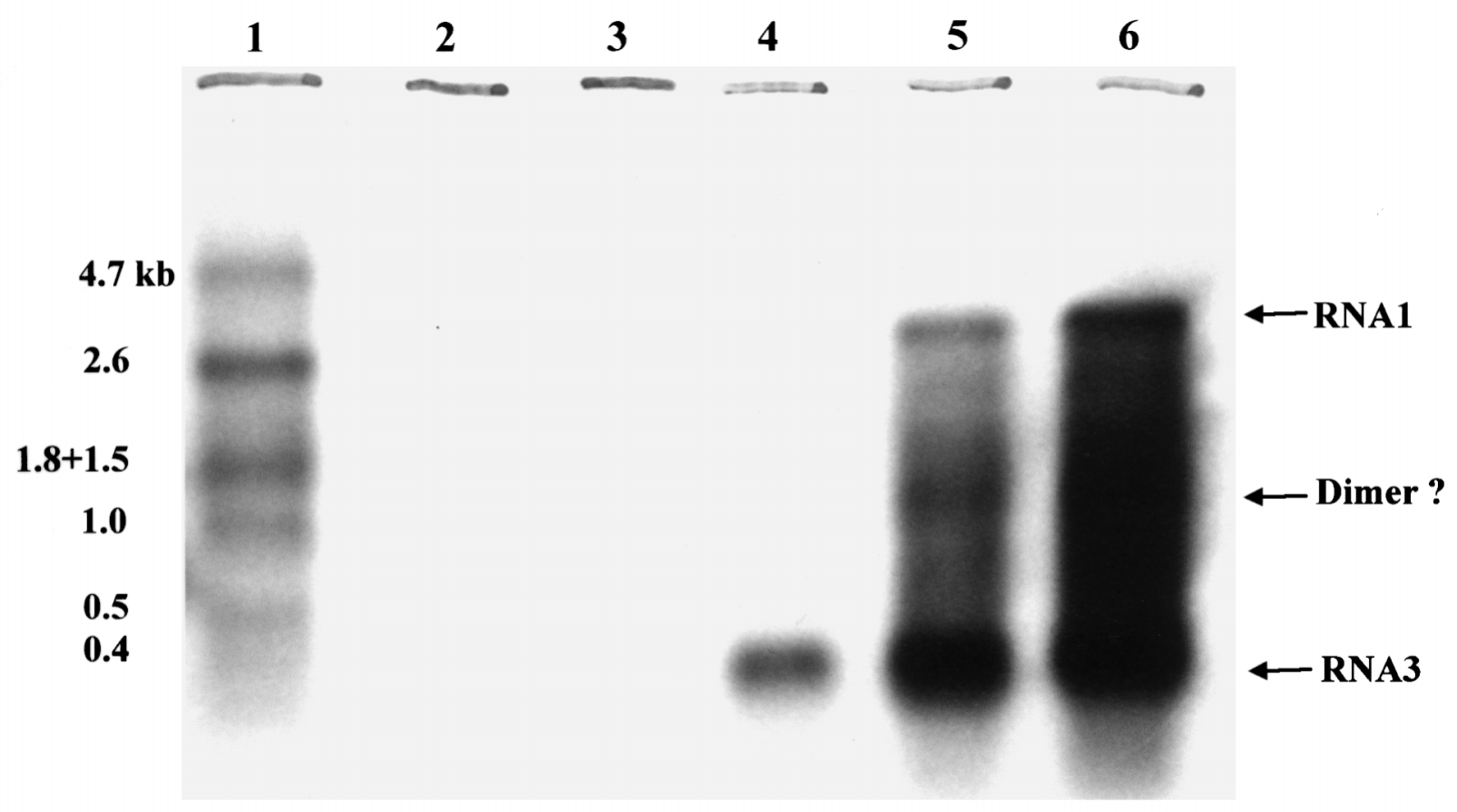

Fig. 3. Northern blot analysis of total cellular RNA isolated from SSN-1 cells infected with AHNV and probed for (+) positivesense RNA1 and RNA3. Lane 1: RNA molecular weight marker (in kb) digoxigenin-labelled (Roche); Lane 2: uninfected control; Lane 3: $8 \mathrm{~h}$ post-infection; Lane 4: $24 \mathrm{~h}$ post-infection; Lane 5: $48 \mathrm{~h}$ post-infection; Lane 6: $120 \mathrm{~h}$ post-infection

dence with the synthesis of RNA3 in BBV- and FHVinfected Drosophila spp. cells at an early stage of infection (Friesen \& Rueckert 1981, Gallagher et al. 1983). In contrast, Delsert et al. (1997) did not detect expression of DIEV RNA3 until $96 \mathrm{~h}$ post-infection in SBL cells, while RNA1 and RNA2 was detected earlier, at $24 \mathrm{~h}$ post-infection. No negative-sense RNA3, RNA1 or RNA2 was detected on the Northern blot; this could have been due to a very low copy number of negative-sense RNA.

The start of the AHNV RNA3 sequence lies downstream of the start codon of the putative B1 protein, indicating that the B1 protein is not expressed during AHNV infection. In most natural eukaryotic mRNAs, the start site for translation is the first AUG codon downstream of the $5^{\prime}$ end (Kozak 1999), and it is therefore unlikely that the ribosomes will scan RNA1 until it faces the putative start codon for protein B1 at Nucleotide 2692 (on its way it will meet 37 AUGs). Unless there is a second subgenomic RNA or a cleavage of RNA1 (which is not likely to produce a functional transcript), the B1-ORF is probably not expressed in AHNV-infected cells. One ORF of 75 codons, in the +1 reading frame compared to ORF-A, was evident within the AHNV RNA3 sequence. This ORF, called ORF-B2, showed significant sequence similarities with the B2 ORF identified in the RNA1 sequence of GGNNV (85\% identity) and SJNNV (79\% identity). Alignments with the much longer insect nodavirus B2 proteins (Johnson et al. 2001) showed no obvious sequence similarities. The B2 protein encoded by FHV has recently been identified as a potent RNAsilencing inhibitor (Li et al. 2002). Although the putative B2 proteins of the fish nodaviruses differed from the insect nodaviruses, the presence and conservation of this ORF strongly indicates that the B2 protein is also important for fish nodavirus replication. However, the presence of the B2 protein in nodavirus-infected fish cells remains to be demonstrated.

Acknowledgements. We thank Dr P. Frost and Dr A. M. Szilvay for valuable comments during the preparation of this manuscript. This project was financed by the Norwegian Research Council.

\section{LITERATURE CITED}

Albarino CG, Price BD, Eckerle LD, Ball LA (2001) Characterization and template properties of RNA dimers generated during flock house virus RNA replication. Virology 289: 269-282

Altschul SF, Madden TL, Schäffer AA, Zhang J, Zhang Z, Miller W, Lipman DJ (1997) Gapped BLAST and PSIBLAST: a new generation of protein database search programs. Nucleic Acids Res 25:3389-3402

Aspehaug V, Devold M, Nylund A (1999) The phylogenetic relationship of nervous necrosis virus from halibut (Hippoglossus hippoglossus). Bull Eur Assoc Fish Pathol 19: 196-202

Ball LA (1992) Cellular expression of a functional nodavirus 
RNA replicon from vaccinia virus vectors. J Virol 66: 2335-2345

Ball LA (1995) Requirements for the self-directed replication of flock house virus-RNA-1. J Virol 69:720-727

Ball LA, Li Y (1993) Cis-acting requirements for the replication of flock house virus RNA2. J Virol 67:3544-3551

Dannevig BH, Nilsen R, Modahl I, Jankowska M, Taksdal T, Press CM (2000) Isolation in cell culture of nodavirus from farmed Atlantic halibut Hippoglossus hippoglossus in Norway. Dis Aquat Org 43:183-189

Dasgupta R, Ghosh A, Dasmahapatra B, Guarino LA, Kaesberg P (1984) Primary and secondary structure of black beetle virus RNA2, the genomic messenger for BBV coat protein-precursor. Nucleic Acids Res 12:7215-7223

Dasmahapatra B, Dasgupta R, Ghosh A, Kaesberg P (1985) Structure of the black beetle virus genome and its functional implications. J Mol Biol 182:183-189

Delarue M, Poch O, Tordo N, Moras D, Argos P (1990) An attempt to unify the structure of polymerases. Protein Eng 3:461-467

Delsert C, Morin N, Comps M (1997) Fish nodavirus lytic cycle and semipermissive expression in mammalian and fish cell cultures. J Virol 71:5673-5677

Eckerle LD, Ball LA (2002) Replication of the RNA segments of a bipartite viral genome is coordinated by a transactivating subgenomic RNA. Virology 296:165-176

Frerichs GN, Rodger HD, Peric Z (1996) Cell culture isolation of piscine neuropathy nodavirus from juvenile sea bass, Dicentrarchus labrax. J Gen Virol 77:2067-2071

Friesen PD, Rueckert RR (1981) Synthesis of black beetle virus proteins in cultured Drosophila cells: differential expression of RNA-1 and RNA-2. J Virol 37:876-886

Friesen PD, Rueckert RR (1982) Black beetle virus: messenger for protein-B is a subgenomic viral-RNA. J Virol 42: 986-995

Gallagher TM, Friesen PD, Rueckert RR (1983) Autonomous replication and expression of RNA-1 from black beetle virus. J Virol 46:481-489

Grotmol S, Totland GK, Kvellestad A, Fjell K, Olsen AB (1995) Mass mortality of larval and juvenile hatchery-reared halibut (Hippoglossus hippoglossus L.) associated with the presence of virus-like particles in vacuolated lesions of the central nervous system and retina. Bull Eur Assoc Fish Pathol 15:176-180

Grotmol S, Totland GK, Thorud K, Hjeltnes BK (1997) Vacuolating encephalopathy and retinopathy associated with a nodavirus-like agent: a probable cause of mass mortality of cultured larval. Dis Aquat Org 29:85-97

Grotmol S, Bergh O, Totland GK (1999) Transmission of viral encephalopathy and retinopathy (VER) to yolk-sac larvae of the atlantic halibut Hippoglossus hippoglossus: occurrence of nodavirus in various organs and a possible route of infection. Dis Aquat Org 36:95-106

Grotmol S, Nerland AH, Biering E, Totland GK, Nishizawa T (2000) Characterisation of the capsid protein gene from a nodavirus strain affecting the atlantic halibut Hippoglossus hippoglossus and design of an optimal reverse-transcriptase polymerase chain reaction (RT-PCR) detection assay. Dis Aquat Org 39:79-88

Guarino LA, Ghosh A, Dasmahapatra B, Dasgupta R, Kaesberg P (1984) Sequence of the black beetle virus subgenomic RNA and its location in the viral genome. Virology 139:199-203

Harper TA (1994) Characterization of the proteins encoded from the nodaviral subgenomic RNA. PhD thesis, University of Wisconsin, Madison

Iwamoto T, Mise K, Mori K, Arimoto M, Nakai T, Okuno T
(2001) Establishment of an infectious RNA transcription system for striped jack nervous necrosis virus, the type species of the betanodaviruses. J Gen Virol 82: 2653-2662

Johnson KN, Zeddam JL, Ball LA (2000) Characterization and construction of functional cDNA clones of pariacoto virus, the first alphanodavirus isolated outside Australasia. J Virol 74:5123-5132

Johnson KN, Johnson KL, Dasgupta R, Gratsch T, Ball LA (2001) Comparisons among the larger genome segments of six nodaviruses and their encoded RNA replicases. J Gen Virol 82:1855-1866

Johnson SC, Sperker SA, Leggiadro CT, Groman DB, Griffiths SG, Ritchie RJ, Cook MD, Cusack RR (2002) Identification and characterization of a piscine neuropathy and nodavirus from juvenile Atlantic cod from the Atlantic coast of North America. J Aquat Anim Health 14:124-133

Johnson KL, Price BD, Ball LA (2003) Recovery of infectivity from cDNA clones of nodamura virus and identification of small nonstructural proteins. Virology 305:436-451

Kaesberg P, Dasgupta R, Sgro JY, Wery JP, Selling BH, Hosur MV, Johnson JE (1990) Structural homology among 4 nodaviruses as deduced by sequencing and X-ray crystallography. J Mol Biol 214:423-435

Koonin EV, Dolja VV (1993) Evolution and taxonomy of positive-strand RNA viruses: implications of comparativeanalysis of amino acid sequences. Crit Rev Biochem Mol Biol 28:375-430

Kozak M (1999) Initiation of translation in prokaryotes and eukaryotes. Gene 234:187-208

Li HW, Li WX, Ding SW (2002) Induction and suppression of RNA silencing by an animal virus. Science 296:1319-1321

Longworth JF, Archibald RD (1975) A virus of black beetle, Heteronychus arator (F) (Coleoptera: Scarabaeidae). NZ J Zool 2:233-236

Mathews DH, Sabina J, Zuker M, Turner DH (1999) Expanded sequence dependence of thermodynamic parameters improves prediction of RNA secondary structure. J Mol Biol 288:911-940

Miller DJ, Ahlquist P (2002) Flock house virus RNA polymerase is a transmembrane protein with amino-terminal sequences sufficient for mitochondrial localization and membrane insertion. J Virol 76:9856-9867

Munday BL, Kwang J, Moody N (2002) Betanodavirus infections of teleost fish: a review. J Fish Dis 25:127-142

Nagai T, Nishizawa T (1999) Sequence of the non-structural protein gene encoded by RNA1 of striped jack nervous necrosis virus. J Gen Virol 80:3019-3022

Nishizawa T, Furuhashi M, Nagai T, Nakai T, Muroga K (1997) Genomic classification of fish nodaviruses by molecular phylogenetic analysis of the coat protein gene. Appl Environ Microbiol 63:1633-1636

Poch O, Sauvaget I, Delarue M, Tordo N (1989) Identification of 4 conserved motifs among the RNA-dependent polymerase encoding elements. EMBO (Eur Mol Biol Organ) J 8:3867-3874

Reinganum C, Bashiruddin JB, Cross GF (1985) Boolarra virus: a member of the Nodaviridae isolated from Oncopera intricoides (Lepidoptera: Hepialidae). Intervirology 24:10-17

Sambrook J, Russell DW (2001) Molecular cloning: a laboratory manual. Cold Spring Harbor Laboratory Press, New York

Scherer WF, Hurlbut HS (1967) Nodamura virus from Japan: a new and unusual arbovirus resistant to diethyl ether and chloroform. Am J Epidemiol 86:271-285

Schneemann A, Reddy V, Johnson JE (1998) The structure 
and function of nodavirus particles: a paradigm for understanding chemical biology. Adv Virus Res 50:381-446

Scotti PD, Dearing S, Mossop DW (1983) Flock house virus: a nodavirus isolated from Costelytra zealandica (White) (Coleoptera: Scarabaeidae). Arch Virol 75:181-189

Tan C, Huang B, Chang SF, Ngoh GH, Munday B, Chen SC, Kwang J (2001) Determination of the complete nucleotide sequences of RNA1 and RNA2 from greasy grouper (Epinephelus tauvina) nervous necrosis virus, Singapore strain. J Gen Virol 82:647-653

Thompson JD, Higgins DG, Gibson TJ (1994) Clustal W: improving the sensitivity of progressive multiple sequence alignment through sequence weighting, position-specific gap penalties and weight matrix choice. Nucleic Acids Res 22:4673-4680

Totland GK, Grotmol S, Morita Y, Nishioka T, Nakai T (1999) Pathogenicity of nodavirus strains from striped jack

Editorial responsibility: Jo-Ann Leong,

Kaneohe, Hawaii, USA
Pseudocaranx dentex and atlantic halibut Hippoglossus hippoglossus, studied by waterborne challenge of yolksac larvae of both teleost species. Dis Aquat Org 38: 169-175

Zeddam JL, Rodriguez JL, Ravallec M, Lagnaoui A (1999) A noda-like virus isolated from the sweetpotato pest Spodoptera eridania (Cramer) (Lep. Noctuidae). J Invertebr Pathol 74:267-274

Zhong W, Rueckert RR (1993) Flock house virus: down-regulation of subgenomic RNA3 synthesis does not involve coat protein and is targeted to synthesis of its positive strand. J Virol 67:2716-22

Zuker M, Mathews DH, Turner DH (1999) Algorithms and thermodynamics for RNA secondary structure prediction: a practical guide. In: Barciszewski J, Clark BFC (eds) RNA biochemistry and biotechnology. Kluwer Academic Publishers, Dordrecht, Netherlands, p 11-43

Submitted: January 24, 2003; Accepted: August 1, 2003 Proofs received from author(s): January 21, 2004 